\title{
How to make a deal: the role of rankings and personal ties in creating trust in the mergers and acquisitions market
}

\author{
Valérie Boussard ${ }^{1}$, Olivier Godechot ${ }^{2, *}$ and Nicolas Woloszko ${ }^{3}$ \\ ${ }^{1}$ Department of Sociology, Université Nanterre Paris-Ouest La Défense, Nanterre, France; \\ ${ }^{2}$ Department of Sociology, Sciences Po, MaxPo and OSC-CNRS, Paris, France and holder of the \\ AXA-Sciences Po Chair of Economic Sociology and ${ }^{3}$ Economics Department, OECD, Paris, France \\ *Correspondence: Olivier.Godechot@sciencespo.fr
}

\begin{abstract}
On the mergers and acquisitions (M\&A) market, buyers and sellers resort to experts in order to secure deals. But as these experts might be prone to opportunism, firms need to find a way to build trust. We identify two trust devices: social ties and public rankings. We explore whether these personal and impersonal devices are substitutes, independent or complementary. We study the French M\&A market through a mixed-method approach. We show that both previous contacts and league table rankings of firms contribute to trust and to making deals. These trust devices are all the more likely to be used if the deal is risky, especially within the sell side (more at risk). We also find that firms tend to make deals only with other firms at the same level in the rankings. Finally, we find some evidence of substitution between rankings and personal ties, especially for low-value deals.
\end{abstract}

Key words: trust, networks, rankings, finance

JEL classification: G24, L14, L15

\section{Introduction}

At the end of the 20th century, economic sociology contributed substantially to the understanding of markets in showing how critical is market actors' embeddedness in personal networks (Granovetter, 1985; Baker, 1990; Uzzi, 1996; Uzzi, 1997; Uzzi, 1999). These networks consist of long-term ties that institute trust and help to solve the classical problem of opportunism in principal-agent relations (Coase, 1937; Williamson, 1975; Granovetter, 1985; Williamson, 1985). However, the computerization of the economy in the last decades may challenge the centrality of personal networks for collecting information and enhancing 
trust. Public rankings based on large, encompassing datasets also help to meet this goal, especially in new online markets such as Amazon, Uber and AirBnb. They provide an impersonal access to information on partners' quality. Actors do not need to stick to previous deal partners or to solicit information from contacts (Fourcade and Healy, 2017).

The role of market devices did not go unnoticed and a new pragmatic sociology (inspired by science and technology studies) showed how market devices helped actors coordinate with each other and build trust. Market devices 'perform the market', i.e. ensure the sheer existence of the market (Thévenot, 1984; Callon, 1998; Callon et al., 2007; Fourcade and Healy, 2017). Among these market devices, public rankings constitute powerful guides for defining and recognizing quality (Espeland and Sauder, 2007; Sauder and Espeland, 2009).

Therefore, although these two resources (networks and market devices) are simultaneously available in almost all markets, they haven't been jointly analyzed by social scientists. Karpik (2010) made a breakthrough in this area and showed how those two resources foster trust. Hence, impersonal public rankings play a crucial role in the markets of fine wines, of films or of literary prizes, and personal networks are detrimental in the market of private lessons or of personalized services (like legal services). In both cases, these resources nourish crucial beliefs that help to overcome the incompleteness of expectations and calculations uniquely based on information and participate in actors' judgments: networks as personal judgment devices, and market devices such as guides and rankings as impersonal judgment devices. Karpik does not yet say whether on a same market these two forms should be thought of as complementary or as substitutes. Answering this question is nevertheless crucial in order to assess the impact of the growing ordinalization of actors through new classification devices in contemporary markets (Fourcade and Healy, 2013, 2017; Fourcade, 2016). If personal and impersonal judgment devices are complementary, the embedded nature of markets remains unchallenged and social capital hierarchies are maintained and increased when transformed into public rankings. If they are substitute, embeddedness and social capital do not constitute anymore the bread and butter of contemporary markets. New public rankings institute new core mechanisms and new foundations for market inequality.

In order to shed light on the nature of the relationship between these two types of judgment devices, one must concentrate on markets where the quality of the goods is particularly complex and its assessment can be done through multiple actors and sources of evaluation. The mergers and acquisitions (M\&A) market thus comes across as a perfect case to study how personal and impersonal judgment devices interact: it is indeed an opaque market where the quality of goods and services is highly uncertain and where this uncertainty initiates a specular process of verification with the help of supplementary information whose quality also needs to be verified (James, 1907). Ending this endless process of verification is a matter of trust and beliefs on the validity of others' verifications (James, 1907).

M\&A operations are indeed unpredictable and often lead to substantial losses (Gugler et al., 2003; Cartwright and Schoenberg, 2006; Appelbaum and Batt, 2014). In order to make a deal, buyers and sellers must agree on the value of the company being bought. That is no easy task, given that the buy and sell sides have opposing interests, and that competing valorization methods exist (Beunza and Garud, 2007; Ortiz, 2015). When embarking on such complex, risky, and dramatic deals, firms request help from market intermediaries, who both reduce uncertainty with regard to the transaction outcome and contribute to displacing it. Firms need to be convinced that intermediaries are following their client's agenda 
rather than their own. The initial uncertainty over the value of the deal morphs into an uncertainty about the quality and integrity of market intermediaries.

The M\&A market is characterized by both close bonds and openness. Market actors are strongly connected to one another. Meanwhile, new actors pop in on a regular basis and generate turnover. Some market players may thus have been in place for a long time and benefit from a broad network, whereas younger firms may lack relevant professional relationships. The M\&A market is made of a broad range of heterogeneous and heteronymous transactions. Market journals and official rankings thus appear to create visibility and clarity. They produce a hierarchy of actors and transactions (Fourcade, 2016) and introduce ordinality in a discrete chaos. Official rankings are somehow self-enforcing; they serve as jungle guides, especially to those entering the market.

Relying on a mixed-method approach, we show how firms in the French M\&A market combine personal networks and professional rankings to foster trust and cope with uncertainty. We confirm existing results about the importance of long-run repeated collaboration on the market. We also show that repeated collaborations between firms often derive from past collaboration between individuals that have worked together in the same firm previously. We confirm that in the case of the M\&A market, public rankings create a status hierarchy and enable firms at the top to grab the lion's share. Finally, we investigate whether the two judgment devices (personal and impersonal) are complementary or substitutes. We find a substantial effect of substitution at the firm level. This result suggests that new market classification contributes to a new market order which differs from traditional reputations spreading through word of mouth.

This article is organized as follows. In the Section 2, we review previous literature on the sociology of markets more extensively in order to describe the possible trust mechanisms at play. In the Section 3, we draw on detailed fieldwork to corroborate and more adequately specify these mechanisms. Section 4 deals with the quantitative methodology. Section 5 describes the statistical results. Section 6 concludes with a discussion on the limits and scope of those results.

\section{Trusting intermediaries in opaque business-to-business markets}

\subsection{Coping with uncertainty}

In markets where complex products are being sold, such as the M\&A market, actors face valuation uncertainty (Boussard, 2013; Chiappello and Gilbert, 2013). There is no one best way to evaluate the object of a transaction, and the best methods available leave room for negotiation. In order to overcome such uncertainty, acquirers and sellers resort to market intermediaries that may be viewed as prescribers of value (Hatchuel, 1995; Bessy and Chauvin, 2013)—such as financial analysts, bankers or auditing firms (Haunschild, 1994) in the case of M\&A. These intermediaries use their expertise to determine the value of the goods being exchanged.

Hiring market experts, however, does not fully eliminate market uncertainty. It displaces the uncertainty from the quality of the good exchanged to that of the market intermediaries, and to the trust one has in their judgment and expertise. Hence, external advisors can be of uncertain quality, and may indulge in opportunistic behaviors, defined as 'self-interest seeking behaviors with guile' (Williamson, 1979). Market intermediaries are better informed than their clients, given that their clients have no other hint at the value of the good that is 
being traded. They may exploit this informational advantage in the very same way that real estate agents would (Levitt and Syverson, 2008). An estate agent who sells a house has an incentive to make a faster transaction, and thus to lower the price, at the expense of the seller. Other examples of opportunism can be found among market makers (Abolafia, 1996). They also have a tendency to 'sell the market' and increase the number of transactions at the expense of their own clients. Moreover, they frequently speculate on the predictable impact of their clients' orders ('front running').

Hence, carrying out both the valuation and the trading of a given good gives actors an informational advantage that can pave the way for opportunism. The remuneration of market intermediaries-which depends on the total volume of transactions-may divert them from their clients' best interests (Dobbin and Jung, 2016).

\subsection{Trust for reducing uncertainty}

The market of M\&A intermediaries is thus an opaque market where the quality of goods and services cannot be easily assessed. Karpik (2010) dubs 'singularities' such goods or services, whose multiple dimensions are incommensurable, and whose quality face a problem of radical uncertainty (Knight, 1921). In markets where singularities are traded, quality is assessed by an act of judgment rather than calculation. Judgment is grounded in knowledge and value in order to integrate the heterogeneity of the criteria. Contrary to the neoclassical theory, information is not the cornerstone of the quality assessment process. Knowledge and value do not exist per se. They 'equip' the market (Karpik, 2010, p. 43), i.e. are shaped into market devices (certifications, rankings, labels, etc.) in order to ease judgment. These devices reduce the cognitive deficit in markets of singularities. Following Knight (1921), Karpik also suggests that in such markets, uncertainty cannot be fully dissipated by knowledge only. Trust has to be added as a way to overcome uncertainty. Indeed, trust turns uncertainty into certainty because the judgment about the quality of the products is rendered credible. With trust, knowledge is completed by belief in this knowledge.

Therefore, market devices are both judgment and trust devices (Karpik, 2010, p. 55), as they provide knowledge and belief to reduce uncertainty. Karpik divides them into two main categories: impersonal and personal. Impersonal devices are appellations, critics and guides (cicerones), rankings or buyers channeling techniques (confluences) that signal quality. They contribute to singling out products for their supposedly outstanding quality. They are akin to the socio-technological devices that frame the markets through the definition and delimitation of categories and qualities (Thévenot, 1984; Callon, 1998; Callon et al., 2007). Personal devices are networks composed of interpersonal relations -family, members, friends, work colleagues, and other contacts. They operate by 'circulation of the spoken word' (Karpik, 2010, p. 45), and provide insiders with credible information about products and people involved in relationship.

Relying on Karpik's argument that actors in opaque markets resort to trust devices in order to overcome uncertainty, we investigate the use of such trust devices by the firms that contract with market intermediaries.

\subsection{Signs of quality as impersonal trust devices}

Following Karpik, public rankings—in the case of M\&A, 'league tables' published by dedicated reviews-serve as impersonal trust devices in opaque business-to-business markets. The rankings of intermediaries help mitigate uncertainty and establish trust in the valuators. 
Hence given their anchoring role in the construction of collective belief in the value of assets traded, we can expect that intermediaries who are ranked the best will get an important share of the market, and that their share will be all the more important if the deal is risky. These hypotheses may come across as trivial, but they are not. According to the economics of quality (Chamberlin, 1953), high-quality and high-market shares are often antithetical. High-quality products usually receive a small portion of total demand. Sports cars, for instance, account for a much smaller amount of total demand than popular cars. Quality generates demand, but competition in quality ushers in equilibrium where exchange for high-quality goods is scarce.

Opaque business-to-business markets disobey the model of economics of quality described by Chamberlain for the following reasons:

First, acquirers may value a small difference in quality all the more when the quality is high. That distinctive shape of the preference for quality leads to a 'superstar' market (Rosen, 1981). In that case, the biggest chunk of the demand goes to a few 'superstars', whose quality is at least slightly higher than their competitors'. The strong preference for quality, coupled with characteristics of the technology, leads to a 'winner-takes-all market' (Frank and Cook, 1996).

Second, Eccles and Crane (1988) argue that the ranked firms performing a high volume of transactions are 'in the deal stream': they conduct large numbers of transactions, and by so doing, gain knowledge about more profitable opportunities. They create numerous market ties with various actors on the market, recruit more people, maintain a high level of activity and gain more experience. Rankings therefore initiate and confirm a self-enforcing dynamic of monopolization of market activity, well described as a 'Matthew effect' (Merton, 1968).

These arguments converge in showing that rankings are used to judge the quality of intermediaries and to decide which of them can be trusted. We can predict that ranked intermediaries will conduct more deals and be hired for the riskier ones.

\subsection{Networks as personal trust devices}

It is now well established that networks between firms convey information (Burt, 1992; Granovetter, 1973). Moreover, networks and embeddedness also appear as a factor in supporting trust (Granovetter, 1985; Coleman, 1988). Burt (2005) argues that 'closure'-i.e. a close system of intertwined connections in a given social world, stabilizes reputations and builds trust. Trust may also arise from direct non-commercial ties. Di Maggio and Louch (1998) provide a strong empirical argument to establish that consumers rely on social relationships to help them with shopping. Brian Uzzi (1996, 1997 and 1999) assesses the impact of social ties both between firms and their banks and between firms and their contractors in the garment industry. He shows that social ties, due to their informational dimension, increase the chance of getting a loan and affect its price. In the case of deals with subcontractors, strong ties (embedded ties) add something more to the simple information flow: they help problem-solving among transaction partners and, moreover, limit opportunism and favor some form of altruism. They are, therefore, more efficient than arm's length ties alone, although the combination of close and distant relationships on the market finally proves to be the most efficient. Baker (1990) provides a similar analysis of how firms do and should distribute their market ties across a set of investment banks. The more often a firm makes deals with a given investment bank, the more trust emerges between them, and the less 
competitive their relationship becomes, which subsequently leads to higher costs. Firms thus strike a balance between trust and efficiency through the use of bybrid models of market ties. Mizruchi and Stearns (2001) also investigate the impact of social networks within a big bank on reducing uncertainty regarding their corporate clients. They argue that in cases of high uncertainty, actors resort to a small network of close and trustworthy colleagues, thus losing the informational diversity of their broader, scarcer network. Finally, when they study the M\&A market more specifically, Eccles and Crane (1988) also stress the importance of ties: 'the M\&A market plays two parts: an interface between buyers and sellers, and a pricing operator. The first part implies informational ties; the second, ties that are capable of bearing value judgment.'

What is the nature of ties that foster trust? Where do they come from? Baker (1990) and Uzzi $(1996,1997)$ consider that some commercial ties become 'embedded' when repeated (Zuckerman, 2004) and therefore foster trust, while others remain at 'arm's length' by selecting their partners on the basis of an invitation to tender. Consequently, their results raise the question of which ties are thus more likely to be repeated. Similarity-especially similarity of social, cultural and educational background-probably plays an important role (McPherson et al., 2001). But behind ties one also frequently finds other ties-either indirect ties of the same nature, such as recommendation from a direct contact, or previous ties of a different nature. A fruitful approach is probably to focus on past shared experience, especially 'dormant ties' (Levin et al., 2011) such as co-working relationships that can be reawakened. Although the impact of the latter on output such as recruitment or contracts has received little attention so far, some recent studies suggest that in finance, past coworking relationships do indeed matter, either for deal-making or for recruiting (Rider, 2012; Godechot, 2014).

There is solid theoretical evidence that embedded ties create trust in opaque environments. We thus expect that actors in the M\&A market pick their business partners along the lines of personal ties.

\subsection{Combining personal and impersonal trust devices}

Academic scholars use different definitions of trust, which can be characterized by the two polarities highlighted by Zucker (1986). The first one defines trust as the assumption that actors involved in an exchange will put self-interest aside and avoid opportunism. For the second one, trust is defined as a set of expectations shared by all members of a relationship. Most of the time, as in Karpik's work, trust is defined as a combination of the two definitions presented above. Beyond their differences, many scholars insist on the way trust is produced and 'manufactured' (Zucker, 1986) and evolved over time (Zaheer et al., 1998; Lount and Pettit, 2012; Schilke and Cook, 2013).

Scholars interested in the varieties of trust and their eventual combination focused mainly on the congruence between the individual level, i.e. the production of trust between individuals (Lount and Pettit, 2012) and the organizational level, i.e. the production of trust between organizations or within institutions (Ring and Van de Ven, 1992). Indeed, the coexistence of these two levels has raised questions about their articulation (Currall and Inkpen, 2006; Poppo, 2013): are they two distinct levels, singled out by different types of trust and trust production mechanism (Zaheer et al., 1998), or are they different stages or forms of the same phenomenon (Stahl and Sitkin, 2005; Schilke et al., 2017)? To put it differently, do individual and organizational levels combine or exclude themselves to produce trust? 
However, this literature did not explore the relation between this question and the typepersonal or impersonal—of trust devices involved (Karpik, 2010). Personal judgment devices based on interpersonal networks involve individuals. These devices generally stand at an individual level. Impersonal judgment devices, like the use of rankings, can easily enter organizational routines and as such produce trust in organizations. Hence, focusing on trust devices would also help to understand the relevant level (individual or organizational) at which trust coalesces.

Karpik (2010) helped to think the duality of trust of devices and the typical domain in which each type is useful. He explains for instance how personal devices are useful for finding a lawyer, while impersonal devices such as rankings count toward finding a good restaurant or a good wine. Therefore, in the case studies he dwells on, the two kinds of trust devices seem at first sight to be substitutes. However, Karpik gives no theoretical insights as to how the two levels of trust are articulated within the same market and how market actors choose the devices to use when intending to reduce uncertainty. Favereau (2010) studies this question for the market of legal services and finds some levels of substitution: independent lawyers rely on networks to find clients, while law firms used impersonal judgment devices to develop their market. Here, this substitution effect is linked to the existence of different market niches depending on the market's actor size (individual versus organization) and the type of legal services (civil law versus corporate law).

Therefore, the two devices may first be thought of as functional substitutes, given that they both aim at providing a remedy against uncertainty. If a firm is singled out in the rankings, it makes personal ties less necessary in order to trust its competence. It also works the other way around: if one knows a professional personally and is assured of their competence and loyalty, the fact that the firm has been singled out in the league tables would only bring a small amount of extra trust. Substitution will be all the more likely if both of the trust mechanisms are costly. Indeed, choosing ranked intermediaries is costly at first sight, because they charge higher fees; whereas personal ties do not have a clear direct monetary price. Nevertheless, if we follow Uzzi (1996), the concentration of trade on some embedded ties is profitable up to a certain threshold, at which point it sterilizes the renewal of ideas. As both forms of trust can incur costs, this should lead actors to favor one trust device over the other.

Nevertheless, substitution may be mitigated by several conflicting mechanisms. First, actors who are more embedded in personal networks may refrain from embarking on such tight arbitrage since overly opportunistic, calculative behavior contradicts social solidarity (Lawler and Yoon, 1996; Latour and Callon, 1997). Second, when the value at risk is very high, one trust device alone may not be sufficient to foster trust. Third, public rankings, when they are multiple and contradictory, require some interpretation and some personal guidance to be used (Coslor, 2016). Finally, the status theory developed by Joel Podolny (2010) suggests that the trust devices should be complementary, at least at the top of the status hierarchy. Status homophily implies path dependence of career tracks: high-status firms recruit people coming from elite universities, who are thus likely to be connected to one another in their past work-related network (Useem, 1984; Useem and Karabel, 1986). Subsequently, it would be all the more likely that the professionals working for two ranked firms involved in the same deal are connected, if only because professionals who work for elite firms belong to a small world of status distinction. 
Both hypotheses—complementarity or substitutability—-thus seem plausible, with the latter being slightly more likely. We shall now turn to empirical fieldwork and statistical analysis to tell them apart.

\section{Ethnographic fieldwork}

\subsection{How to make a deal}

A corporate transaction involves the sale of a firm by its owner (seller) to a buyer (refer Appendix for a description of the fieldwork). Sellers and buyers employ various intermediaries to carry out the various functions necessary to the making of a deal: financial advisors (often investment banks), accountants (usually auditing firms), corporate bankers, lawyers. Every transaction can be seen as a confrontation between the buy-side and sell-side 'teams.'

The making of a deal follows a formal process, encompassing the production of different forms and reports, leading to a negotiation between the seller and the buyers, through their team of advisors. The process gives rise to particularly careful stages of confrontation: each team is on one side of a long table, and discussions are led by two team officials, placed one in front of the other. The two teams present their visions of the company, the seller seeking to embellish, the buyer seeking to uncover weaknesses in order to better negotiate the price.

If you sell, your job is to tell a great story about the company on Power Point. Conversely, when you buy, you must dissect the documents presented by the other firm in order to know more about possible gains. (CFO, Male, 37 years, ex-financial advisor)

Analysts from both sides issue financial indicators to determine the value of the target company. There is no one best way to calculate the value of a firm. The plurality of methods and the use of forecasts grant analysts room for maneuver. Hence, an investment banker claims 'not to find the value (of the company), but to optimize it.' In other words, the valuation methods are not used as if they were revealing the value of a company.

They need to be reassured. They want to believe in our forecasts, even though they may seem fanciful. We play, we manipulate. In these expert businesses, the problem is that you're supposed to be an expert ... it's like when you take a big decision in life: you talk to friends, loved ones. Well here, the manager, he spoke to experts, to reassure themselves. We are here to sell! (A financial advisor)

The transaction process aims at ensuring that the buying and the selling sides agree on a certain idea of the value of the target firm, and subsequently on a transaction price. What is at stake in these transactions is the production of a legitimate-not objective-judgment on the value of companies. Intermediaries merely need the actors around the table to believe in the calculation they make, so their arguments about the fair price of the transaction have an impact.

We build (financial) modeling and make a parameter move, to see how it reports to credit. One may choose to believe it or not." (A financial advisor)

Hence a 'financial advisor,' a partner of a reputed international firm, explains that his job is 'to produce the objective value according to [Firm's name]'. That oxymoron is at the heart 
of the valuation operation: it is about making people believe, by various methods, that the resulting value is unquestionable. The belief in the value is all the more important because, as we shall see in the next subsection, the calculation of the value can lead to conflicts of interest between clients and market intermediaries.

\subsection{Opportunism in the making of a deal, and trust in valuators}

As many market intermediaries are paid with market fees proportional to the value of the transaction, the main risk of opportunism with financial intermediaries is that they might indulge in overselling. Market intermediaries may aim at closing the deal because of some financial profit or gain in reputation, sometimes at the expense of the client, who could either be paying an excessive price for the target company or selling it at a discount price.

More subtle forms of opportunism lie in the divergence of interests between the buyer or the seller and their market intermediaries in terms of the financial rules they apply. Buyers or sellers may expect their intermediaries' loyalty to go beyond deontology and to break professional rules so as to match clients' interests. Intermediaries are therefore always striking a balance between serving their present clients' interests and managing their long-term reputations. This is made clear by the following discussion between members of an auditing firm working on the drafting of a due diligence report while on a conference call with the client ('CFO')

CFO: 'In paragraph x, I would prefer to remove the "more than", because there is no visibility on this product.' The partner put her hands on her head and said: 'Do not tell me you want us to replace the June figures with those of August?' Then, later on, the CFO continued: 'One of our shareholders was not comfortable: if we write that we are "cautious" in the current environment, the bankers will believe that we have a problem. She just said that we should remove the reasons: 'Let's not give any indication that would scare off the banker!' Katia notes and says 'OK', while visibly not comfortable.

Financial advisors must convince their customers (either buyers or sellers) that the value they have calculated is genuine on the basis of the data produced by accountants. Similarly, bankers who finance the acquisition must find values (and associated risks) appropriate to the company for which they grant funding. As a lender explains, they have 'to take Excel and to believe that the company would grow and to believe in its valuation'. Yet, they have to believe in the value displayed in the reports, even though they know about all the inherent weaknesses of valuation:

On the buyers' side, due diligences reports are also reviewed by funds. For instance, 'highly pessimistic' is transformed into 'slightly pessimistic'. That's wording! (A lender)

Therefore, the uncertainty about the value is displaced to uncertainty about the valuator. The issue for buyers or sellers is whether or not they have to trust the intermediaries they are paying for assessing the target company. This trust not only implies confidence in the data and figures delivered, but also confidence in the way the intermediaries will interpret them and defend their points of view, giving credence to the valuation. These two sources of uncertainty are connected: the more trustworthy the market intermediaries, the more legitimate their judgment on the value appears to be, and the stronger the belief in the company's value. 


\subsection{How rankings are used as impersonal trust devices}

When asked about how they choose the market intermediaries they work with, some interviewees often refer to their reputation and prestige. Intermediaries are aware that customers are sensitive to their references ('credentials'), defined as the list of previous transactions and their characteristics ('volume', 'prestige').

It's having a big turnover and many customers: making large transactions. A beautiful merger with a recognized customer. The 'credentials': see advertisement about it. (A financial advisor)

The higher the uncertainty, the more market actors will seek these signs of prestige. They do not necessarily believe in the quality they claim to guarantee, but they believe other actors give credit to it.

We take an investment bank when it is a big operation, where you need a guarantee: we pay for their name. (Financial director, head of M\&A in a CAC 40 firm)

Hence, rankings are useful for newcomers entering the market, since they can serve as shortcuts for identifying who counts and which actors have the legitimacy for establishing value. But they are not less important for insiders willing to use them as a status confirmation device. Therefore, it is no surprise that interviewees insist on the role of rankings, both for intermediary firms (banks, auditing firms, etc.) and for individuals (managers, partners).

One of the most-used rankings on the French M\&A market, the league tables, are defined by Capital Investissement, which produces them, as 'arithmetic rankings made according to the value or number of transactions on which they intervened'. Although they first seem to indicate high market share, they are also used as an indicator of high quality. The league tables single out and rank a small number of firms (approximately 10\% in most cases) in each industry (investment banking, auditing, strategy consulting, financial advice, etc.) and in each market segment (small, mid-sized, large capitalization).

Investment banks are proud of these rankings, so they send them to you. This is the League Tables system. There are subcategories: if a bank is in two categories, this is no coincidence. They really have to be good [...]. There are moguls: they are first in all the rankings, and they think they can call the boss [to propose an acquisition], and sometimes it works. (Financial director, head of M\&A in a CAC40 firm)

These rankings also provide the opportunity for awards ceremonies that grant firms and individuals outstanding visibility. The trophies earned materialize a high-status reputation and are exhibited in the offices or waiting rooms. The performative dimension of these rankings is acknowledged by the actors themselves

About this event: it is organized by a magazine (Décideurs) that nobody reads because it is bad. This is a much-criticized medium because it is very marketing-oriented; they sell contacts and publish ads. But they manage to gather 600 persons to the awarding ceremonies, thanks to those phony rankings they make. The best positions are held by the biggest advertisers in the magazine. Some firm had a prize one year, as it had withdrawn its advertising budgets on the previous year. When we got the prize we had it on our website and acquired new customers thanks to that. Wholesale, rankings, nobody believes them, but they have an effect, so we continue. (Partner of an auditing firm: Observation of Leaders League trophies ceremony) 
Consequently, rankings, and the status they give, seem to have an influence on market intermediaries' pairings:

What's great [after this award] is that we are doing great operations: people want to work with us, we have become one of the three strongest teams in Paris, along with BNP [and] Calyon, which was rebuilt at the same time as us." (A financial advisor)

Hence, the fieldwork on the French M\&A market suggests that rankings contribute to creating confidence, both in valuators and in valuation. They thus set the bases for the negotiation process. Ranked firms have more chance to engage in deals and are more likely to match with one another.

\subsection{Ties in practice}

But rankings do not seem to be the only way to solve the issue of trust in the market for intermediaries.

The links made on the occasion of a past work experience are frequently cited as a source of confidence, and take two forms. The first form consists of past co-working relationships (Levin et al., 2011; Rider, 2012; Godechot, 2014): people worked together as colleagues in the service of the same employer. They had the opportunity to work together on an operation, often with a relationship of subordination. Respondents value these bonds.

This is a superb address book: all those with whom I have worked, I see them again because we all have wrestled with that so much that we are very close. This is a great school. I advise everyone even if it seems a bit masochistic." (Former junior financial advisor)

The second form consists of repeated business ties, thereby turning them into 'embedded ties' (Baker, 1990; Uzzi, 1996). The actors can thus choose to work with someone they knew on the occasion of another transaction. For example, in a previous transaction, a financial advisor may have encountered a team of accountants whose work he valued highly, even perhaps on the adverse side. He can decide to call them in a subsequent transaction. 'People you've seen on other transactions, that you saw in action, it is a trusted network that is created.'

The importance of seeing people at work, especially in the workplace, seems linked to the high labor-intensity demanded in this industry. Transactions are conducted at a steady pace, including work on nights and weekends, with acute phases during the final negotiations. Being able to rely on the availability of people and their acceptance of working conditions is frequently cited as crucial.

They are extremely demanding. They loved me because I reassured them by being always available for them. They liked me because I was sending e-mails at 4:00 a.m. In this business obedience brings recognition. You have to accept to make super boring tasks in extreme conditions. (A financial advisor)

Ties are generally used to foster trust within teams on the same side of the deal (buy side or sell side).

Therefore, the fieldwork suggests that professional connections matter for choosing teams of intermediaries. 


\subsection{Combining rankings and personal ties}

Our ethnographic data does not shed much light on the articulation of the two levels of trust to which market actors resort. For instance, asked whether networks and rankings are complementary or substitutes in the choice of an intermediary, a private equity investor had difficulty answering. After a long hesitation, he said they were substitutes, but ended up saying it depended on a variety of factors. In fact, in his firm they consider that rankings are more like window dressing, and they do not give much importance to them. Contrary to other firms, which are used to setting up competition between multiple arm's-length ties (Baker 1990; Uzzi 1996), his firm would rather work with long-term embedded ties they can trust. His firm would hire ranked firms mainly for big deals in order to prove their status. They would then hire them as credit enhancers, along with their usual embedded advisors, who would still do most of the job.

The qualitative material backs our theoretical insights that market actors rely heavily on both personal and impersonal trust devices. However, neither fieldwork nor market actors themselves provided sufficient evidence to prove or disprove the hypothesis that the two forms of devices are substitutes. We, thus, turn to a statistical analysis of the M\&A market to settle that question.

\section{Statistical data and method}

\subsection{Data and variables}

We constructed a deal dataset based on 664 transactions published every week in 2010 by a French professional outlet called Capital Finance, devoted to investment and mergers and acquisitions. ${ }^{1}$ The date of publication provides a 50 -week longitudinal dimension to the data. Among those deals, 1280 different firms and 3286 persons were involved (Cf. Table 1).

We also constructed a curriculum vitae (CV) dataset with the résumés of the accountants, bankers, financial advisers and buyers involved in these deals found on LinkedIn. Sellers are never described in Capital Finance. Since we focused mainly on finance professionals rather than on lawyers, whose careers, reputations and networks obey a very different rationale, we only investigated the career tracks and personal ties of the former. We found $839 \mathrm{CVs}$ out of a pool of 1990 persons (excluding the lawyers), among which 730 were complete enough for statistical exploitation $(37 \%)$.

We therefore restricted our study to the 389 firms for which we knew the CV of at least one participant $(46 \%$ of the firms-law firms excluded). Due to our restriction of the

1 Contrary to trading activities, mergers and acquisitions activities were not strongly affected by the global financial crisis which started during the summer 2007 and climaxed in the fall 2008. The number of deals reported by Capital Finance declined by $6 \%$ in 2007 but increased again by $12 \%$ in 2008, $3 \%$ in 2009 and $15 \%$ in 2010 . Therefore, we believe this 2010 database captures ordinary transactions on the M\&A market. 


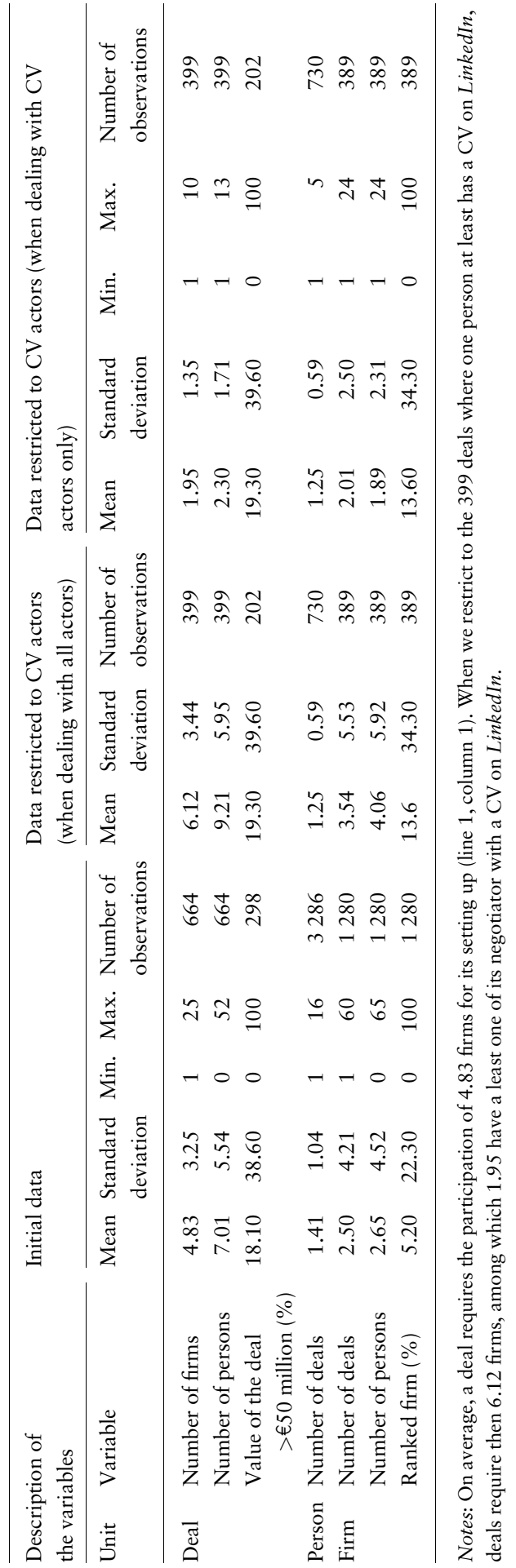


population, we finally studied 399 deals $(60 \%)$. This restriction slightly overweighs major actors (Table 1) but does not drive per se our conclusions. ${ }^{2}$

In order to concentrate on the deal-making between actors (either firms or persons), we design a dataset of dyadic connections between actors which contains both connections between actors $i$ and $j$ that are in the same $d$ deal and counterfactual dyads. In order to design counterfactual dealing partners for each deal, we match each actor $j$ part of deal $d$ with all other $i$ partners that were not part of this deal. ${ }^{3}$ For instance in deal 572 we find five firms (L.E.K Consulting, DC Advisory Partners, Grant Thornton on the sell side; LCL and Natixis on the buy side). In this deal, LCL has therefore four dealing partners, among which one on the same side and 384 non dealing partners which serve as counterfactuals (Table 2).

Our main variables of interest are rankings on the one hand, and personal ties on the other. We used league tables rankings of firms in 2010 provided by http://www.leader sleague.com/. These rankings of M\&A firms in 23 specialties (organized by industries, size of firm, size of the deal, types of actor) are the most consensual rankings on the French M\&A market and widely monitored. Therefore, they enable to proxy formal trust devices. Leadersleague uses five distinctions to honor the most renowned firms (most firms are not ranked). As most firms $(86 \%)$ are not ranked, we consider the fact of being distinguished in at least one leader's league ranking to be a good indicator of public certification.

In order to capture collaboration ties between firms (Rider, 2012; Godechot, 2014), we used three indicators: alumni ties, work ties and deal ties.

Thanks to CVs collected on LinkedIn, we coded 'alumni ties', as the fact of having graduated from the same higher education institution. This might imply sometimes that the two persons have met there. However, it might more often imply a form of mutual recognition. Two alumni, especially those from the same Grande École (Bourdieu, 1996), who did not know each other during higher education are likely to recognize themselves as members of the same club (and like to discover common acquaintances) and would therefore feel close.

We created a proxy for co-working ties using the career tracks of all the professionals we found on LinkedIn. We surmise that two professionals are likely to be connected if they worked together in the same firm during at least 1 year of their career. In large firms, working together does not necessarily mean knowing each other and having a tie. However, while we do not know the size of the firms in which actors had their previous job, both the

2 Individuals who post a curriculum vitae (CV) on LinkedIn differ slightly from those who do not: they work for larger firms, which are more often ranked, involved in a higher number of deals and larger ones as shown by the number of dealing partners (Table 1). Our reduction of the datasets to deals between CV actors is therefore more likely to represent the large transactions between the key market players. For variables that do not depend on the Linkedln dataset, we also compared the correlation between deal-making and judgments devices. Hence, Table 2 shows that ranked firms have 2.6 times more chances in initial dataset of entering the transaction. This is very similar to the odds ratio of 2.2 in the reduced dataset. Past dealing ties also multiplies the probability of a new deal by similar magnitude in the two datasets (6.73 versus 8.05 ). Results of the regressions also show similar results and will be sent on request. Therefore, we feel that the reduction of the dataset to firms and deals where actors have their CV on Linkedln does not introduce any substantial bias.

3 Conditioning on the presence of $j$ in the deal $d$ enables us to avoid the computation of a matrix of 60 million of dyads $\left(\mathrm{n}_{i} \times \mathrm{n}_{j} \times \mathrm{n}_{d}=389 \times 389 \times 399\right)$, a size for which the estimation of logistic regression would be difficult. Moreover, studying the probability of a dyadic tie between $i$ and $j$ in deal $d$ when neither $i$ nor $j$ are in the deal $d$, adds little relevant information to the final estimation. 
Table 2. First order correlations between the main variables

\begin{tabular}{|c|c|c|c|c|c|c|c|}
\hline \multicolumn{2}{|c|}{ Description of the variables } & \multicolumn{3}{|c|}{ Initial data } & \multicolumn{3}{|c|}{$\begin{array}{l}\text { Data restricted to CV actors (when } \\
\text { dealing with CV actors only) }\end{array}$} \\
\hline Unit & Variable & $\begin{array}{l}\text { Dealing } \\
\text { dyads }\end{array}$ & $\begin{array}{l}\text { Counter- } \\
\text { factual }\end{array}$ & All dyads & $\begin{array}{l}\text { Dealing } \\
\text { dyads }\end{array}$ & $\begin{array}{l}\text { Counter- } \\
\text { factual }\end{array}$ & All dyads \\
\hline \multirow[t]{5}{*}{ Firm dyads } & Number of dyads & 19314 & 4084997 & 4104311 & 1474 & 301942 & 303416 \\
\hline & $\begin{array}{c}\text { Firm } i \text { ranked in } i j \\
\text { dyad }\end{array}$ & $12.5 \%$ & $5.2 \%$ & $5.2 \%$ & $24.9 \%$ & $13.5 \%$ & $13.6 \%$ \\
\hline & Alumni ties & & & & $32.3 \%$ & $17.2 \%$ & $17.3 \%$ \\
\hline & Co-worker ties & & & & $8.0 \%$ & $2.1 \%$ & $2.1 \%$ \\
\hline & Previous co-deal ties & $9.3 \%$ & $1.5 \%$ & $1.5 \%$ & $6.6 \%$ & $0.87 \%$ & $0.90 \%$ \\
\hline \multirow{4}{*}{$\begin{array}{l}\text { Person dyads } \\
\text { (from different } \\
\quad \text { firms) }\end{array}$} & Number of dyads & 44218 & 15137565 & 15181583 & 2036 & 660819 & 662855 \\
\hline & Alumni ties & & & & $3.4 \%$ & $3.7 \%$ & $3.7 \%$ \\
\hline & Coworker ties & & & & $1.5 \%$ & $0.80 \%$ & $0.80 \%$ \\
\hline & Previous co-deal ties & $1.0 \%$ & $0.13 \%$ & $0.14 \%$ & $0.60 \%$ & $0.08 \%$ & $0.08 \%$ \\
\hline
\end{tabular}

Notes: The initial DEAL database enables to establish 19314 dyads of firms dealing together and 4084997 counterfactual dyads where firm $i$ does not participate to the deal in which $j$ is involved. Among the dealing dyads, $12.5 \%$ of $i$ dealing partners are ranked, $9.3 \%$ are previous co-deal ties.

fieldwork and a few checks on a handful of firms involved showed that the M\&A milieu is constituted either of small boutiques or of small departments within large financial firms. For instance, in 2010 firms had maximum 65 and on average 2.65 persons involved in 2010 deals (Table 1). Given the importance of teamwork in this activity, having worked at least one same year in the same firm is a reasonable proxy for work collaboration.

Third, we exploit the longitudinal dimension of our 52 weeks' deal database in order to code a 'previous co-deal tie', as two actors' previous co-participation in a same deal, either on the same side or on different sides (buy versus sell) of the deal. The intensity of work and of interactions during the setting up of the deal is likely to derive in a longer term relationship that can be used for further deal opportunities. While it is true that a 1 -year period is a limited time span for capturing long-term deal ties, we believe that our variable is a proxy of the most significant long-term dealing ties: only the most repeated dealing ties have a chance of being captured by our variable. ${ }^{4}$

We consider that two firms are linked by 'alumni ties', 'work ties' or 'deal ties' when at least two of their respective workers in the deal database are linked with such ties. Because firm ties are derived from individual ones, we will check whether they have similar impact on the formation of dealing dyads both at the individual and the firm level (Table 2, Table 3 and Table A1 in the Appendices). Finally, due to the limited information used for their coding, it is likely that our proxies for ties largely underestimate the multiplex links structuring the field. Even though our data only captures the tip of the iceberg, it still provides information on how ties make a difference in the setting up of a deal.

4 Given that the 'manual' setting up of the database was very time consuming, we did not investigate for a longer time span. Future research that could access pre-constituted databases could help to push forward the role of long-term dealing ties. 


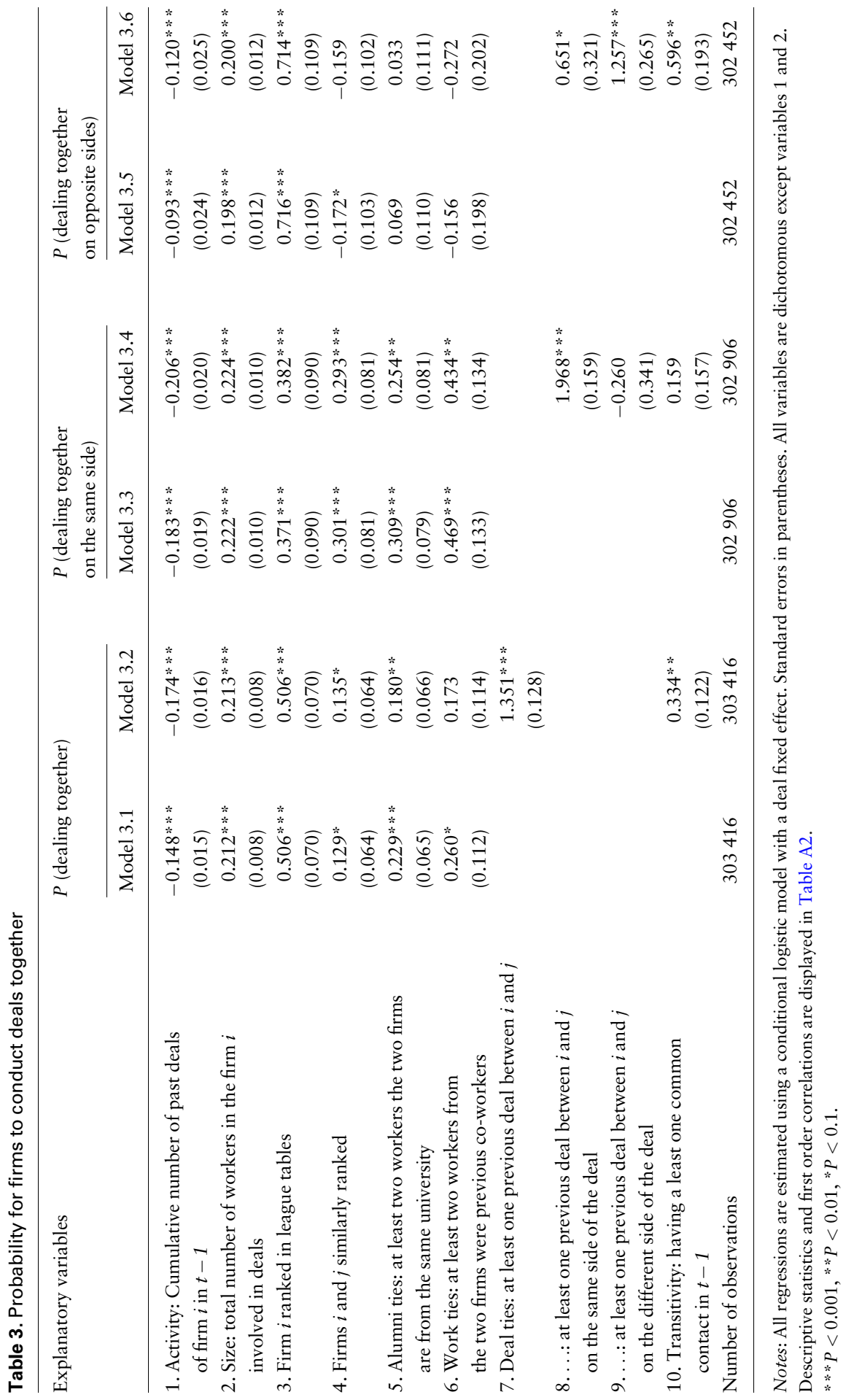




\subsection{Estimation}

We model the making of a deal using conditional logistic regressions. The 52 weeks longitudinal dimension of our data enables us to introduce the lagged structure of the network as a predictor of deal making between two actors at time $t$. Using lagged variables avoids the endogeneity problem of explaining the network structure by itself. Therefore, logistic regressions, already used similarly in previous studies (Gulati and Gargiulo, 1999; de Nooy, 2011; Rider, 2012), offer a great deal of flexibility and enable us to study many effects.

We explain the probability of being in the same deal $d$ than $j$ conditionally to $j$ 's presence in the deal by the attributes of $i(A i)$ or by attribute similarity between $i$ and $j\left(A_{i} \approx A_{j}\right)$, by previous social ties $T_{i j t-1}$ between $i$ and $j$, and by past network structure $D_{i j(t-1)}$ such as activity or transitivity. In order to capture unobserved deal characteristics that could bias our estimates, we also introduce a deal fixed effect $d^{5}$. This fixed effect controls for all deal specificities, starting with its size. Therefore, the model could be summarized by Equation (1) (with $f$ being the logistic function and $u$ the residuals).

$$
P\left(D_{i j d}=1 \mid j \text { is in deal } d\right)=f\left[a_{1} A_{i}+a_{2}\left(A_{i} \approx A_{j}\right)+a_{3} T_{i j(t-1)}+a_{4} D_{i j(t-1)}+d+u\right]
$$

We apply Model (1) to two different levels of actors, firms and persons. The link $D_{i j d}=1$ will be considered to represent making a deal together overall, on different side of the deal or on the same side of the deal. Given that the ranking, one of our key independent variables, is defined at the firm level, we will focus mainly on firm-level regressions (Tables 3 and 4). However, because ties between firms derive from ties between persons, we will check whether the results for ties at the firm level also hold true at the individual level (Table A1).

\section{Results}

\subsection{Rankings}

First, league table rankings appear to be a strong and significant predictor of deal-making in all tables (Table 3, Line 3). It multiplies the likelihood of entering the deal by 1.4 [i.e. $\exp (0.371)]$ to 1.7 [i.e. $\exp (0.506)]$. In a context of strong uncertainty about the quality of services provided, public rankings signal trustworthiness (especially to sellers and buyers). Ranked actors might be better at making deals, or their clients might believe they are-or their clients might think that others (such as the other side or the markets) believe they are, and they want to signal that they are setting up a high-quality team.

Through the use of interactions, our regressions also show that rankings count more on the sell side than on the buy side (Table 4, Model 4.5, Line 14). Securing the deal for the sell side is paramount to the seller, since the quality of the sell side directly impacts the shortterm profits (or losses). The buy side may also be impacted when the price of the transaction rises above a certain threshold. However, except for very important deals monitored by the markets, this does not translate into short-term profits as directly as it does for the sell side. We also show that the rankings are more impactful (at 10\% significance threshold) when it comes to connecting two firms who have different roles (e.g. financial advisor versus

5 An anonymous referee of this article suggested as an alternative strategy to introduce actor fixed effects instead of deal-fixed effects. We checked that actor $j$ fixed effects yielded very similar results. Results will be sent on request. 
Table 4. Probability for two firms to conduct deals together within the same side (i.e. sell side or buy side).

\begin{tabular}{|c|c|c|c|c|c|c|}
\hline Explanatory variables & Model 4.1 & Model 4.2 & Model 4.3 & Model 4.4 & Model 4.5 & Model 4.6 \\
\hline 1. Firm $i$ ranked in league tables rankings & $\begin{array}{l}0.538 * * * \\
(0.096)\end{array}$ & $\begin{array}{l}0.520 * * * \\
(0.097)\end{array}$ & $\begin{array}{r}-0.463 * \\
(0.210)\end{array}$ & $\begin{array}{r}-0.392 * \\
(0.229)\end{array}$ & $\begin{array}{c}0.187^{*} \\
(0.099)\end{array}$ & $\begin{array}{l}0.617^{* * *} \\
(0.139)\end{array}$ \\
\hline $\begin{array}{l}\text { 2. Work ties: total number of years workers } \\
\text { from the two firms worked in common }\end{array}$ & $\begin{array}{l}0.741^{* * *} \\
(0.157)\end{array}$ & & $\begin{array}{l}0.483 * \\
(0.280)\end{array}$ & & & \\
\hline $\begin{array}{l}\text { 3. Deal ties: cumulative number of previous } \\
\text { deals between } i \text { and } j \text { (same side) }\end{array}$ & $\begin{array}{l}2.091 * * * \\
(0.173)\end{array}$ & & $\begin{array}{l}2.512^{* * *} \\
(0.302)\end{array}$ & & & \\
\hline $\begin{array}{l}\text { 4. All ties (sum of deal ties and } \\
\text { work ties) }\end{array}$ & & $\begin{array}{l}1.065^{* * *} \\
(0.135)\end{array}$ & & $\begin{array}{l}1.224 * * * \\
(0.251)\end{array}$ & $\begin{array}{l}0.875^{* * *} \\
(0.122)\end{array}$ & $\begin{array}{l}0.387^{*} \\
(0.225)\end{array}$ \\
\hline 5. Firm ranked $\times$ work ties & $\begin{array}{l}-0.913^{* *} \\
(0.279)\end{array}$ & & & & & \\
\hline 6. Firm ranked $\times$ deal ties & $\begin{array}{r}-0.696^{*} \\
(0.395)\end{array}$ & & & & & \\
\hline 7. Firm ranked $\times$ all ties & & $\begin{array}{l}-0.953 * * * \\
(0.242)\end{array}$ & & $\begin{array}{r}-0.523 \\
(0.554)\end{array}$ & & \\
\hline $\begin{array}{l}\text { 8. Value of the deal }>€ 50 \text { million } \times \\
\text { firm ranked }\end{array}$ & & & $\begin{array}{l}1.318 * * * \\
(0.239)\end{array}$ & $\begin{array}{l}1.346 * * * \\
(0.257)\end{array}$ & & \\
\hline $\begin{array}{l}\text { 9. Value of the deal }>€ 50 \text { million } \times \\
\text { work ties }\end{array}$ & & & $\begin{array}{r}-0.578 \\
(0.358)\end{array}$ & & & \\
\hline $\begin{array}{l}\text { 10. Value of the deal }>€ 50 \text { million } \times \\
\text { deal }\end{array}$ & & & $-1.077 * *$ & & & \\
\hline ties & & & $(0.412)$ & & & \\
\hline $\begin{array}{l}\text { 11. Value of the deal }>€ 50 \text { million } \times \\
\text { all ties }\end{array}$ & & & & $\begin{array}{r}-0.662 * \\
(0.347)\end{array}$ & & \\
\hline $\begin{array}{l}\text { 12. Value of the deal }>€ 50 \text { nillion } \times \\
\text { firm ranked } \times \text { all ties }\end{array}$ & & & & $\begin{array}{r}-0.359 \\
(0.684)\end{array}$ & & \\
\hline 13. Sell side & & & & & $\begin{array}{l}-1.383^{* * *} \\
(0.189)\end{array}$ & \\
\hline 14. Sell side $\times$ firm ranked & & & & & $\begin{array}{l}1.237 * * * \\
(0.256)\end{array}$ & \\
\hline 15. Sell side $\times$ all ties & & & & & $\begin{array}{l}-1.272^{* *} \\
(0.454)\end{array}$ & \\
\hline 16. Same role & & & & & & $\begin{array}{l}0.662 * * * \\
(0.115)\end{array}$ \\
\hline 17. Same role $\times$ firm ranked & & & & & & $\begin{array}{r}-0.409^{*} \\
(0.207)\end{array}$ \\
\hline 18. Same role $\times$ all ties & & & & & & $\begin{array}{r}-0.450 \\
(0.283)\end{array}$ \\
\hline Number of observations & 302906 & 302906 & 161484 & 161484 & 302906 & 136150 \\
\hline
\end{tabular}

Notes: All regressions are estimated using a conditional logistic model with a deal fixed effect. Standard errors in parentheses.

$* * * P<0.001,{ }^{* * P} P<0.01,{ }^{*} P<0.1$. Other control variables are similar to Table 3, Model 3.3. They yield similar results. 
accountant, or banker versus seller) (Table 4, Model 4.6, Line 17). Uncertainty is higher between different professions than among the same professions. In other terms, one needs to resort to ranking when picking partners in other professions more than when picking partners in one's own profession. Rankings count more when the value of the deal is higher than $€ 50$ million (Table 4, Models 4.3 and 4.4 Line 8), showing that reducing uncertainty through the choice of ranked partners is all the more important because the value of the deal is important.

We then investigated whether status similarity counts for setting up deals. For this purpose, our main variable is the similarity in rankings achieved between actors $i$ and $j$. Ranking similarity clearly favors connection at the firm level (Table 3, Models 3.1 to 3.4, Line 4). Ranking similarity is more important within the same side than between sides at the firm level (Table 3, Models 3.3 and 3.4 versus 3.5 and 3.6, Line 4). This result is in line with the fact that status similarity favors connection in cooperative structures (McPherson et al., 2001), while it could lead to conflict in competitive structures (Gould 2002). ${ }^{6}$

\subsection{Ties}

We do not know exactly in what order actors in a deal are chosen, or by whom they are chosen. Although sellers (or buyers) formally decide on the constitution of the sell-side team (or, respectively, the buy side team), they are advised by financial advisors (or, respectively, by bankers, accountants or lawyers) on whom to choose in order to constitute the team. The actors could therefore advise people they trust because they share a common educational, work or deal experience. In our regressions, connections are another strong predictor of deal-making. While alumni ties between firms seem to favor deal making (Table 3, Line 5), it's not the case at the individual level (Table A1, Line 4). On the opposite, work ties (having worked previously together in the same firm) and past deal ties (having worked previously on the same deal together) contribute significantly and strongly to deal connection, especially within the same side of the deal, both at the firm level (Table 3, Model 3.4, Lines 6 and 8 ) and the individual level (Table A1, Model A1.4, Lines 5 and 7). Therefore, the congruence of work and deal ties at both levels suggest a relational dynamics of personal work ties translating into firm deal ties and deal ties being repeated from one deal to another.

Through interactions or variation in the definition of the sample, we investigate the conditions that favor the use of ties for deal-making. Hence, work ties favor more deal-making within the same side of the deal (Table 3, Model 3.3, Line 8) than between different sides of the deal (Table 3, Model 3.5). Ties are also more often used for deals of small value below $€ 50$ million (Table 4, Models 4.3 and 4.4, Lines 9 and 11).

These results confirm that work ties and previous deal ties are a way of establishing trust. First, within the same side of the deal, you need to cooperate with people you trust, and choosing among former colleagues is a clear way to enforce a high level of trust. Second, repeated collaboration is more likely to foster trust within the same professional arena.

\subsection{Combining rankings and ties}

Rankings and ties (especially work ties) follow the same logic overall. They favor dealmaking, especially among different roles on the sell side. But there are some small variations:

6 We would like to thank an anonymous reviewer for this suggestive interpretation. 
rankings are used more for high-value trades, while work ties have no link with the value of the trade (and deal ties have a negative link).

Our results confirm the substitution hypothesis. Models 4.1 and 4.2 in Table 4 show that while ranking and ties increase the probability of making deals, their combination decreases it (Lines 5 and 7). The substitution effect does not seem to decrease for deals of high value (Model 4.4).

\section{Conclusion}

Through a mixed-method analysis of the setting of deals in the French M\&A sector, our article sheds light on deal making in opaque business-to-business markets. Our article contributes to the existing literature in economic sociology by showing how, in practice, actors combine both socio-technical devices' performing quality and bonding network ties, two phenomena that have generally been disconnected by previous literature. It demonstrates that M\&A professionals resort to both personal and impersonal trust devices in order to control risks of opportunism and to make deals. For French M\&A, it confirms that rankings contribute to the establishment of a status hierarchy and to its stratification by status levels (Podolny, 2010). It shows that the embedded market ties (through long-term repetition) shown by Uzzi (1996) and Baker (1990) are frequently past co-working ties (Rider, 2012). Moreover, our paper also studies the combination of these two trust devices. The statistical analysis shows some evidence of substitution between ranking and personal ties.

However, suggestive these results may be, they suffer from limitations that further research needs to overcome. First, the results may be due to some unobserved confounding variables, and a natural experiment would be welcome in order to establish more thoroughly the true causal impact of the two devices. Second, the precise micro-mechanisms at play in the use of these devices require further elucidation both at a qualitative and a quantitative level. Third, this case study, which was limited to French M\&A, would greatly benefit from comparison with other case studies of opaque business-to-business markets in different institutional settings.

Finally, the substitutability of the two trust devices, if confirmed beyond the French M\&A market, can help to think some of the consequences of the present increase in 'classifications situations' (Poon, 2009; Fourcade and Healy, 2013) and to explore further the dialectical dynamic of personal and impersonal judgment devices.

One must recall that most contemporary public rankings like online reputations rely on the aggregation of personal judgments. They are nevertheless detached from their personal origin and thus provide impersonal guidance to actors looking for market partners. The substitutability of the two-judgment devices as shown in the article, the declining costs of public rankings and their growing presence, could in a first step challenge the centrality of personal ties, lead to a fracturing of the inner circle and favor a more open society. In a second step, further progress in substitution might lead to a disappearance of markets' embeddedness and to a new market closure based on public hierarchies. In such a world, low-status actors will not only make fewer deals because they are less visible, but they will also conclude less favorable ones with ranked actors. Indeed, the latter willing to maximize their position in rankings are less constrained than embedded actors by a sense of commitment and could overlook deal partners that do not matter on their rankings. However, in a final stage, this evolution could also jeopardize the foundations of this new market order. If market actors, informed mainly by public rankings, engage less in personal judgments, public rankings based on the aggregation could become less reliable, more path dependent and unpredictable (Sagalnik et al., 
2006). Another scenario is also possible as the evolution described above is far from certain: public rankings as they multiply bring more complexity to the market and require personal guidance by experts who can tell which public ranking to use and how to use it (Coslor, 2016). Paradoxically, they reintroduce personal judgment to become useful trust devices.

Therefore, these contradictory evolutions are a plea in favor of new empirical research on the long-term dynamic of personal and impersonal judgment devices and its impact on the market order.

\section{Acknowledgements}

In an early phase of this work, Sylvain Thine contributed substantially to the constitution of the statistical dataset. We are very grateful for helpful comments from Heather Haveman and Allison Rovny on a previous version of this article.

\section{Funding}

Data collection was funded by French research agency Agence Nationale de la Recherche in 2010 through the funding of the CARFI project (ANR-JCJC 2010).

\section{References}

Abolafia, M. (1996) Making Markets: Opportunism and Restraint on Wall Street, Cambridge, MA, Harvard University Press.

Appelbaum, E. and Batt, R. (2014) Private Equity at Work: When Wall Street Manages Main Street, New York, NY, Russell Sage Foundation.

Baker, W. (1990) 'Market Networks and Corporate Behavior', American Journal of Sociology, 96, 589-625.

Bessy, C. and Chauvin, P-M. (2013) 'The Power of Market Intermediaries: From Information to Valuation Processes', Valuation Studies, 1, 83-117.

Beunza, D. and Garud, R. (2007) 'Calculators, Lemmings or Frame-makers? The Intermediary Role of Securities Analysts', The Sociological Review, 55, 13-39.

Bourdieu, P. (1996) The State Nobility: Elite Schools in the Field of Power, Cambridge, UK, Polity.

Boussard, V. (2013) 'Qui Crée La Création De Valeur?', La nouvelle revue du travail, no. 3, accessed at http://nrt.revues.org/1020 on November 14, 2015.

Burt, R. (1992) Structural Holes: The Social Structure of Competition, Cambridge, MA, Harvard University Press.

Burt, R. (2005) Brokerage and Closure: An Introduction to Social Capital, Oxford, Oxford University Press.

Callon, M. (1998) 'Introduction: The Embeddedness of Economic Markets In Economics', In Callon, M. (ed.) The Laws of the Markets, Oxford, Blackwell, pp. 1-57.

Callon, M., Millo, Y. and Muniesa, F. (2007) Market Devices, Malden, MA, Wiley-Blackwell.

Cartwright, S. and Schoenberg, R. (2006) 'Thirty Years of Mergers and Acquisitions Research: Recent Advances and Future Opportunities', British Journal of Management, 17, S1-S5.

Chamberlin, E. (1953) 'The Product as an Economic Variable', The Quarterly Journal of Economics, 67, 1-29.

Chiapello, E. and Patrick, G. (2013) Sociologie Des Outils De Gestion, Paris, La Découverte.

Coase, R. (1937) 'The Nature of the Firm', Economica, 4, 386-405. 
Coleman, J. (1988) 'Social Capital in the Creation of Human Capital', American Journal of Sociology, 94, S95-S120.

Coslor, Erica. (2016) 'Transparency in an Opaque Market: Evaluative Frictions between "Thick” valuation and "Thin" Price Data in the Art market', Accounting, Organizations and Society, $50,13-26$.

Currall, S. C., Inkpen, A. C. (2006) 'On the Complexity of Organizational Trust: A Multi-Level Co-Evolutionary Perspective and Guidelines for Future Research'. In Bachmann, R. and Zaheer, A. (eds) The Handbook of Trust Research, Cheltenham, Edward Elgar, pp. 235-246.

de Nooy, W. (2011) 'Networks of Action and Events over Time. A Multilevel Discrete-Time Event History Model for Longitudinal Network Data', Social Networks, 33, 31-40.

Dobbin, F. and Jung, J. (2016) 'Agency Theory as Prophecy: How Boards, Analysts, and Fund Managers Perform their Roles', Seattle University Law Review, 39, 291-320.

Eccles, R. and Crane, D. B. (1988) Doing Deals: Investment Banks at Work, Boston, Harvard Business School Press.

Espeland, W. N. and Sauder, M. (2007) 'Rankings and Reactivity: How Public Measures Recreate Social Worlds', American Journal of Sociology, 113, 1-40.

Favereau, O. (ed.). (2010) Les Avocats, Entre Ordre Professionnel et Ordre Marchand, Paris, Lextenso Éditions.

Fourcade, M. and Healy, K. (2017) 'Seeing Like a Market', Socio-Economic Review, 15, 9-29.

Fourcade, M. and Healy, K. (2013) 'Classification Situations: Life-Chances in the Neoliberal Era', Accounting, Organizations and Society, 38, 559-572.

Fourcade, M. (2016) 'Ordinalization', Sociological Theory, 34, 175-195.

Frank, R. and Cook, P. (1996) The Winner-Take-All Society: Why the Few at the Top Get so Much More than the Rest of Us, New York, NY, Penguin Books.

Godechot, O. (2014) 'Getting a Job in Finance. The Strength of Collaboration Ties', European Journal of Sociology, 55, 25-56.

Gould, R. V. (2002) 'The Origins of Status Hierarchies: A Formal Theory and Empirical Test', American Journal of Sociology, 107, 1343-1178.

Granovetter, M. (1973) 'The Strength of Weak Ties', American Journal of Sociology, 78, 1360-1380.

Granovetter, M. (1985) 'Economic Action and Social Structure: The Problem of Embeddedness', American Journal of Sociology, 91, 481-510.

Gulati, R. and Gargiulo, M. (1999) 'Where Do Interorganizational Networks Come From?' American Journal of Sociology, 104, 1439-1438.

Hatchuel, A. (1995) 'Les Marchés à Prescripteurs'. In Jacob, A. and Vérin, H. (eds) L'inscription Sociale du Marché, Paris, L'Harmattan, pp. 203-224.

Haunschild, P. (1994) 'How Much Is That Company Worth?: Interorganizational Relationships, Uncertainty, and Acquisition Premiums', Administrative Science Quarterly, 39, 391-411.

James, W. (1907) Pragmatism, a New Name for Some Old Ways of Thinking; Popular Lectures on Philosophy, New York, NY, Longmans, Green, and Co.

Karpik, L. (2010) Valuing the Unique: The Economics of Singularities, Princeton, NJ, Princeton University Press.

Knight, F. (1921) Risk, Uncertainty and Profit, Boston, MA, Houghton Mifflin.

Lawler, E. and Yoon, J. (1996) 'Commitment in Exchange Relations: Test of a Theory of Relational Cohesion', American Sociological Review, 61, 89-108.

Latour, B. and Callon, M. (1997) “"Thou Shall Not Calculate!” or How to Symmetricalize Gift and Capital'. Translated by Javier Krauel, from Comment peut-on être anticapitaliste 1997, unpublished manuscript, accessed at http://www.bruno-latour.fr/sites/default/files/downloads/ P-71\%20CAPITALISME-MAUSS-GB.pdf on September 1, 2016. 
Levin, D., Walter, J. and Murnighan, K. (2011) 'Dormant Ties: The Value of Reconnecting', Organization Science, 22, 923-939.

Levitt, S. and Syverson, C. (2008) 'Market Distortions When Agents Are Better Informed: The Value of Information in Real Estate Transactions.' The Review of Economics and Statistics, 90, 599-611.

Lount, R. B., Pettit, N. C. (2012) 'The Social Context of Trust: The Role of Status', Organizational Behavior and Human Decision Processes, 117, 15-23.

McPherson, M., Smith-Lovin, L. and Cook, J. M. (2001) 'Birds of a Feather: Homophily in Social Networks', Annual Review of Sociology, 27, 415-44.

Merton, R. (1968). 'The Matthew Effect in Science', Science, 159, 56-63.

Mizruchi, M. and Stearns, L. B. (2001) 'Getting Deals Done: The Use of Social Networks in Bank Decision-Making', American Sociological Review, 66, 647-671.

Ortiz, H. (2015). 'Establishing "Value" Across the Chinese Border: Some Questions about the Relation Between Fieldwork, History and the Transformations of Global Finance', paper presented at the 27th Annual Meeting of SASE, London, England, July 2-4.

Podolny, J. (2010) Status Signals: A Sociological Study of Market Competition, Princeton, NJ, Princeton University Press.

Poon, M. (2009) 'From New Deal Institutions to Capital Markets: Commercial Consumer Risk Scores and the Making of Subprime Mortgage Finance', Accounting, Organizations and Society 34, 654-674.

Poppo, L. (2013) 'Origins of Inter-Organizational Trust: A Review And Query For Future Research'. In Bachmann, R. and Zaheer, A. (eds) Handbook of Advances in Trust Research, Cheltenham: Edward Elgar, pp. 125-145.

Rider, C. (2012) 'How Employees' Prior Affiliations Constrain Organizational Network Change: A Study of U.S. Venture Capital and Private Equity', Administrative Science Quarterly, 57, 453-483. doi:10.1177/0001839212461633.

Ring, P. S, Van de Ven, A. H. (1992) 'Structuring Cooperative Relationships between Organizations', Strategic Management Journal, 13, 483-498.

Rosen, S. (1981) 'The Economics of Superstars', The American Economic Review, 71, 845-858.

Salganik, M. J., Dodds, P. S. and Watts, D. J. (2006) 'Experimental Study of Inequality and Unpredictability in an Artificial Cultural Market' Science, 311, 854-856.

Sauder, M. and Espeland, W. N.(2009) 'The Discipline of Rankings: Tight Coupling and Organizational Change', American Sociological Review, 74, 63-82.

Schilke, O. and Cook, K. S. (2013) 'A Cross-Level Process Theory of Trust Development in Interorganizational Relationships', Strategic Organization, 11, 281-303.

Schilke, O., Wiedenfels, G., Brettel, M. and Zucker, L. G. (2017) 'Interorganizational Trust Production Contingent on Product and Performance Uncertainty', Socioeconomic Review, 15, 307-330.

Stahl, G. K. and Sitkin, S. B. (2005) 'Trust in Mergers and Acquisitions'. In Stahl, G. K. and Mendenhall, M. E. (eds) Mergers and Acquisitions: Managing Culture and Human Resources, Palo Alto, CA, Stanford University Press, pp. 82-102.

Thévenot, L. (1984) 'Rules and Implements: Investment in Forms', Social Science Information, 23, $1-45$.

Useem, M. (1984) The Inner Circle, New York, NY, Oxford University Press.

Useem, M. and Karabel, J. (1986) 'Pathways to Top Corporate Management', American Sociological Review 51: 184-200.

Uzzi, B. (1996) 'The Sources and Consequences of Embeddedness for the Economic Performance of Organizations: The Network Effect', American Sociological Review, 61, 674-698.

Uzzi, B. (1997) 'Social Structure and Competition in Interfirm Networks: The Paradox of Embeddedness', Administrative Science Quarterly, 42, 35-67. 
Uzzi, B. (1999) 'Embeddedness in the Making of Financial Capital: How Social Relations and Networks Benefit Firms Seeking Financing', American Sociological Review, 64, 481-505.

Williamson, O. E. (1975) Markets and Hierarchies: Analysis and Antitrust Implications, New York, NY, Free Press.

Williamson, O. E. (1979) 'Transaction-Cost Economics: The Governance of Contractual Relations', Journal of Law and Economics, 22, 233-261.

Williamson, O. E. (1985) The Economic Institutions of Capitalism, New York, NY, Simon and Schuster.

Zaheer, A., McEvily, B. and Perrone, V. (1998) 'Does Trust Matter? Exploring the Effects of Interorganizational and Interpersonal Trust on Performance', Organization Science, 9, 141-151.

Zucker, L. (1986) 'Production of Trust: Institutional Sources of Economic Structure, 1840-1920', Research in Organizational Behavior, 8, 53-111.

Zuckerman, E. W. (2004) 'Do Firms and Markets Look Different? Repeat Collaboration in the Feature Film Industry, 1935-1995' Unpublished Paper, http://web.mit.edu/ewzucker/www/ look_different.pdf.

\section{Appendix}

\section{Fieldwork methodology}

Data includes interviews, ethnographic observations and documents issued by M\&A professionals.

\subsection{Interviews}

The 76 semi-structured interviews that were conducted focused on three issues: the interviewees' biographical and professional trajectories, their professional activity and the mapping of the professional field. The sample is evenly balanced between the age groups (under 30, between 30 and 40 and over 40), and the hierarchy (junior, team management, senior positions/shareholders). The 76 interviewees work in 48 different firms that cover a representative spectrum of business situations (French and foreign firms of various sizes, seniority, specialization and type of customers). Each interviewee was asked to provide contact information about a few colleagues so that the sample could be designed gradually. In all, $57 \%$ of the respondents graduated from a business school and 4\% from a prestigious engineering school; $71 \%$ are men and $29 \%$ women. The sample structure equates to that of the transaction database (see below), except for an overrepresentation of business school graduates, which results from the absence of people working outside of Paris or London in the sample.

At the time of the interviews, the interviewees held either seller/buyer positions (25) or market intermediary positions (51). The interviews covered past sequences of the interviewees' careers, and thus include descriptions of a greater number of professional positions than the number of interviewees. The total number of professional sequences amounts to 153, among which 85 are sequences as intermediaries, 37 as sellers/buyers and 31 as other financial professionals.

\subsection{Ethnographic observation}

The observation includes three distinct fieldworks. First, we observed the activity and organization of an auditing firm specialized in M\&A over a period of 10 days (including some evenings and nights). We observed the drafting of reports and team and client 
meetings. Second, we observed training sessions designed to equip finance professionals with valuation skills. Third, we participated in meetings and business events (forums, lounges, awards ceremonies).

\subsection{Document analysis}

This research also includes an analysis of documents produced and sent to the M\&A professionals: financial management textbooks and sales brochures.

Table A1. Probability for persons from different firms to conduct deals together

\begin{tabular}{|c|c|c|c|c|}
\hline \multirow[t]{2}{*}{ Explanatory variables } & \multicolumn{2}{|c|}{$\mathrm{P}$ (dealing together) } & \multicolumn{2}{|c|}{$\begin{array}{l}\mathrm{P} \text { (dealing together on } \\
\text { the same side) }\end{array}$} \\
\hline & Model A1.1 & Model A1.2 & Model A1.3 & Model A1.4 \\
\hline $\begin{array}{l}\text { 1. Activity: cumulative number } \\
\text { of past deals of person } i \text { in } t-1\end{array}$ & $\begin{array}{l}-1.786^{* * *} \\
(0.059)\end{array}$ & $\begin{array}{l}-1.809 * * * \\
(0.060)\end{array}$ & $\begin{array}{l}-1.899 * * * \\
(0.075)\end{array}$ & $\begin{array}{l}-1.915^{* * *} \\
(0.075)\end{array}$ \\
\hline 2. Firm of person $i$ ranked & $\begin{array}{l}1.468^{* * *} \\
(0.056)\end{array}$ & $\begin{array}{l}1.463^{* * *} \\
(0.056)\end{array}$ & $\begin{array}{l}1.408^{* * *} \\
(0.074)\end{array}$ & $\begin{array}{l}1.403^{* * *} \\
(0.074)\end{array}$ \\
\hline 3. Firms $i$ and $j$ similarly ranked & $\begin{array}{c}0.062 \\
(0.052)\end{array}$ & $\begin{array}{c}0.062 \\
(0.052)\end{array}$ & $\begin{array}{l}0.298 * * * \\
(0.068)\end{array}$ & $\begin{array}{l}0.296^{* * *} \\
(0.068)\end{array}$ \\
\hline $\begin{array}{l}\text { 4. Alumni ties: coming from the } \\
\text { same university }\end{array}$ & $\begin{array}{r}-0.159 \\
(0.122)\end{array}$ & $\begin{array}{r}-0.169 \\
(0.122)\end{array}$ & $\begin{array}{r}-0.135 \\
(0.151)\end{array}$ & $\begin{array}{r}-0.151 \\
(0.151)\end{array}$ \\
\hline $\begin{array}{l}\text { 5. Work ties: } i \text { and } j \text { worked at least } 1 \text { year } \\
\text { in the same previous firm }\end{array}$ & $\begin{array}{l}0.536^{* *} \\
(0.185)\end{array}$ & $\begin{array}{l}0.500 * * \\
(0.185)\end{array}$ & $\begin{array}{l}0.976^{* * *} \\
(0.187)\end{array}$ & $\begin{array}{l}0.935^{* * *} \\
(0.188)\end{array}$ \\
\hline $\begin{array}{l}\text { 6. Deal ties: at least one previous deal } \\
\text { between } i \text { and } j\end{array}$ & & $\begin{array}{l}2.736^{* * *} \\
(0.295)\end{array}$ & & \\
\hline $\begin{array}{l}7 \ldots . \text { at least one previous deal } \\
\text { between } i \text { and } j \text { on the same side } \\
\text { of the deal }\end{array}$ & & & & $\begin{array}{l}2.643 * * * \\
(0.417)\end{array}$ \\
\hline Number of observations & 662855 & 662855 & 662111 & 662111 \\
\hline
\end{tabular}

Notes: All regressions are estimated using a conditional logistic model with a deal fixed effect. All continuous variables are standardized. Standard errors in parentheses.

$* * P<0.001, * P<0.01, * P<0.1$. 
Table A2. Descriptive statistics and correlations for Table 3

\begin{tabular}{|c|c|c|c|c|c|c|c|c|c|}
\hline & $\begin{array}{l}\text { Mean } \\
\text { (s.d.) }\end{array}$ & 1 & 2 & 3 & 4 & 5 & 6 & 7 & 8 \\
\hline 0. Dealing together & $\begin{array}{l}0.005 \\
(0.07)\end{array}$ & 0.05 & 0.09 & 0.02 & -0.01 & 0.03 & 0.03 & 0.04 & 0.01 \\
\hline $\begin{array}{l}\text { 1. Activity: cumulative number of } \\
\text { past deals of firm } i \text { in } t-1\end{array}$ & $\begin{array}{c}0.961 \\
(1.588)\end{array}$ & 1.00 & 0.69 & 0.16 & -0.07 & 0.16 & 0.13 & 0.17 & 0.18 \\
\hline $\begin{array}{l}\text { 2. Size: total number of workers } \\
\text { in the firm } i \text { involved in deals }\end{array}$ & $\begin{array}{c}1.880 \\
(2.291)\end{array}$ & & 1.00 & 0.22 & -0.09 & 0.23 & 0.20 & 0.13 & 0.11 \\
\hline 3. Firm $i$ ranked in league tables & $\begin{array}{c}0.136 \\
(0.343)\end{array}$ & & & 1.00 & -0.41 & 0.09 & 0.10 & 0.04 & 0.04 \\
\hline 4. Firms $i$ and $j$ similarly ranked & $\begin{array}{c}0.698 \\
(0.459)\end{array}$ & & & & 1.00 & -0.11 & -0.06 & -0.03 & -0.04 \\
\hline $\begin{array}{l}\text { 5. Alumni tie: at least two workers } \\
\text { the two firms are from the same } \\
\text { university }\end{array}$ & $\begin{array}{c}0.172 \\
(0.378)\end{array}$ & & & & & 1.00 & 0.15 & 0.08 & 0.12 \\
\hline $\begin{array}{l}\text { 6. Work ties: at least two workers } \\
\text { from the two firms were previous } \\
\text { co-workers }\end{array}$ & $\begin{array}{c}0.021 \\
(0.144)\end{array}$ & & & & & & 1.00 & 0.07 & 0.11 \\
\hline $\begin{array}{l}\text { 7. Deal ties: at least one previous } \\
\text { deal between } i \text { and } j\end{array}$ & $\begin{array}{c}0.009 \\
(0.094)\end{array}$ & & & & & & & 1.00 & -0.02 \\
\hline $\begin{array}{l}\text { 8. Transitivity: having a least } \\
\text { one common contact in } t-1\end{array}$ & $\begin{array}{c}0.028 \\
(0.164)\end{array}$ & & & & & & & & 1.00 \\
\hline Number of observations & 303416 & & & & & & & & \\
\hline
\end{tabular}

